- cover either various forms of technology transfer or "the possible use of a percentage of any royalties for humanitarian purposes".

John Fleming, director of the Southern Cross Bioethics Institute in Australia, and a member of an international panel set up by Unesco to draw up an international code of bioethics, suggests that there is a need for a body to act as an 'honest broker' to help set up agreements covering topics such as patent rights between researchers and the groups they are studying.

Others want a more political solution. Several Pacific nations, for example, are said to be contemplating asking the UN General Assembly to seek an advisory ruling on the morality of human gene patents from the International Court of Justice.

According to Pat Mooney of RAFI, the ultimate goal of such a move would be to persuade governments to introduce tighter restrictions on human genetic material in the intellectual property provisions of the General Agreement on Tariffs and Trade (GATT), which are due for review in 1999.

But such moves, too, are likely to be highly controversial. Biotechnology companies are already uncomfortable with provisions in the European Patent Convention that allows moral issues to be used to judge eligibility for patentability. Action at the global level allowing for enhanced protection of human genetic material is likely to meet with even stronger opposition.

In contrast, any such proposals are likely to win enthusiastic report from indigenous groups that see the prospect of participating (as subjects) in the search for new genes not

\section{IMAGE UNAVAILABLE FOR COPYRIGHT REASONS}

\section{Navajo indians: will genetic analysis help them achieve a better future?}

as a welcome chance to boost the world's biotechnology industry, but more as a form of modern-day colonialism. David Dickson

\title{
Diversity project: Cavalli-Sforza answers his critics
}

San Francisco. Much of the current controversy about the implications of the genetic screening of population groups has focused - some would argue unfairly so - on the Human Genome Diversity Project (HGDP), a programme of research conceived by Luigi Luca Cavalli-Sforza, the population geneticist and professor emeritus at Stanford University in California.

Cavalli-Sforza, the author of books covering a range of aspects of both biological and cultural evolution, combines genetic, archaeological, linguistic and other cultural data in understanding human evolution. The HGDP, he says, would be a collaborative effort to set up a rational method to study human variation and reconstruct the history of modern ethnic differentiation, as well as providing other scientific and applied benefits.

New techniques of DNA analysis, Cavalli-Sforza points out, provide an unprecedently precise way of analysing the history of human populations. Using such techniques, for example, he has been collaborating since 1984 with Judy and Ken Kidd of Yale University on a pilot project to generate cell lines from two dozen populations throughout the world. So far, more than 100 restriction fragment length polymorphisms (RFLPs) and 100 microsatellite markers have been tested on 15 cell lines, representing populations from each of the five continents.

"Population genetics has been going on since 1917. The HGDP is an effort to make it more efficient, specific and rational," he says, adding that the increasing rate at which populations are mixing (and losing) their genetic uniqueness gives the project considerable urgency.

In all, Cavalli-Sforza foresees sampling about 10 per cent of the world's 5,000 linguistically distinct populations. One use of this information, he says, would be to quantify how language and other cultural characteristics correlate with, and may have influenced, the distribution of genetic profiles throughout the world. He says a careful analysis can do much to counter racist interpretations of such correlations.

$\mathrm{He}$ also argues that the data would help to provide a more balanced perspective of humanity's genetic resources than the Human Genome Project, which so far is focusing on the genetic profile of a mosaic of a few groups of individuals primarily of European origin. Finally, it could yield important information about the genetic basis of disease susceptibility and immunity.

In contrast, Cavalli-Sforza says that the HGDP has no intention of emphasizing research on populations in danger of extinction. This concept, he says, emerged mostly from the media's mistaken interpretation of the project's interest in collecting information rapidly from populations undergoing increasing admixture - a process that in some cases enhances their fertility and survival, but contributes to the disappearance of cultures and makes genetic measurements more difficult.

Indeed, he says that researchers had hoped that a few populations might provide some interesting genetic surprises, and that drawing attention to the plight of some small tribes might attract efforts to help them survive. Genetic research on such groups, he adds, might also help to solve specific problems, such as the low fertility of the Andaman Islanders of India.

Cavalli-Sforza is disturbed by accusations that his work contributes to racist stereotypes. In fact, he says, genetic evidence strongly supports the concept that there are no separate races.

Although the HGDP has come under intense public scrutiny (see Nature $\mathbf{3 7 7}$, 373; 1995), Cavalli-Sforza maintains that this is not unusual for genetic research programmes. But he still admits to being taken aback by the fervour of some attacks on the HGDP, claiming that the project has been misrepresented by its critics - for example, those who have dubbed it the vampire project because it is based on the collection of blood samples - and had not been prepared to correct their interpretation.

The response to scientific projects that raise difficult questions should not be to bar them, but to approach them with care, he says. In this vein, he has already asked the United Nations Educational, Scientific and Cultural Organization to review ethical issues related to the project, in particular compensation in case of commercial applications of the research.

At the same time, he says that he has chosen not to reply directly to some of his critics because he feels they are politically and personally motivated, and not primarily interested in solving genuine problems.

On the question of patents on genetic information obtained during the course of the project, Cavalli-Sforza says his personal view is that there should be no patents on DNA at all. But he feels that the potential commercial value of the information now emerging from the Human Genome Project and related activities may make such a position impossible to sustain.

Indeed, with indigenous people gaining in political influence, he suggests that patents could provide a way for them to exploit their own resources. "In the unlikely event there is some gene that becomes commercially valuable, the people who donated it - not the individual, but the group - should somehow share in the advantages," he says. But, he adds: "How to do it is not so easy."

One decision that he believes is essential, however, is that the HGDP should not accept any corporate funding, precisely to avoid any potential conflict of interest.

Sally Lehrman 